Original Paper

\title{
Meningkatkan Kesadaran Bahaya Sampah Laut Melalui Pendampingan pada Masyarakat Lokasi Wisata Pantai Kuranji
}

\author{
Sukib $^{1 *}$, Muti’ah ${ }^{1}$, Jeckson Siahaan $^{1}$, dan Supriadi ${ }^{1}$ \\ ${ }^{1}$ Program Studi Pendidikan Kimia, Fakultas Keguruan dan Ilmu Pendidikan, Universitas Mataram, Indonesia
}

DOI: $10.29303 /$ jpmpi.v2i2.343

Sitasi: Sukib, Muti'ah, Siahaan, J., Supriadi. (2019). Meningkatkan Kesadaran Bahaya Sampah Laut Melalui Pendampingan pada Masyarakat Lokasi Wisata Pantai Kuranji. Jurnal Pengabdian Magister Pendidikan IPA (JPMPI). (2) 2. pp. 102-106

*Corresponding Author: Sukib, Program Studi Pendidikan Kimia, Fakultas Keguruan dan Ilmu Pendidikan, Universitas Mataram, Indonesia; Email:

suriptobio@unram.ac.id

\begin{abstract}
Abstrak: Telah dilakukan kegiatan penyuluhan tentang bahaya sampah laut. Program ini bertujuan untuk memberikan edukasi/kesadaran kepada masyarakat Pantai Kuranji (Siswa SMP N 17 Mataram) tentang: (1) bahaya sampah (terutama plastik), (2) cara menjaga kebersihan pantai. Kegiatan ini dilakukan dengan metode ceramah, diskusi dan tanya jawab dengan menggunakan media poster. Dari hasil kegiatan ini adalah: (1) Telah dibuat media untuk kegiatan penyuluhan berupa poster tentang pencemaran laut dan efeknya terhadap kehidupan, (2) Hasil observasi, diskusi dan tanya jawab, serta tes sikap siswa, menunjukkan bahwa melalui kegiatan penyuluhan ini pengetahuan siswa tentang bahaya sampah laut meningkat. (3) Kesadaran siswa terhadap bahaya sampah laut meningkat.
\end{abstract}

Kata kunci: Kesadaran; Kesadara; Sampah Laut.

\section{Pendahuluan}

Menurut NOAA (National Oceanic and Atmospheric Administration), sampah laut didefinisikan sebagai benda padat yang dihasilkan oleh manusia, baik secara langsung maupun tidak langsung, sengaja maupun secara tidak sengaja dibuang di dalam lingkungan laut (NOAA, 2013). Sampah laut (marine debris) terutama dari jenis plastik telah menjadi masalah besar di seluruh dunia tak termasuk Indonesia

Di Indonesia, sampah laut menjadi masalah besar dan dilaporkan sebagai produsen sampah plastik ke laut terbesar kedua setelah Cina (Lebreton, 2017; Jambek, 2015). Menurut Kementerian Lingkungan Hidup (KLH), setiap hari orang Indonesia menghasilkan $0,8 \mathrm{~kg}$ sampah atau 189 ribu ton sampah per hari. Sebagian dari total sampah ini dibuang langsung ke perairan dan akhirnya berada di laut.

Sebagian besar limbah plastik akan berakhir di laut dan persentasenya adalah yang terbesar sekitar $60-80 \%$ dibandingkan dengan kaca, besi, gelas dan kertas (Moore, 2012). Jambeck et al. (2015) melaporkan bahwa pada tahun 2010 di
Indonesia sampah dan limbah yang dihasilkan sebesar $0,52 \mathrm{~kg}$ per orang per hari dan $11 \%$ nya adalah plastik. Limbah yang tidak diolah dengan baik dan yang menjadi sampah sebesar 83\%.Limbah plastik yang masuk ke laut di Indonesia diperkirakan mencapai 0,48-1,29 Juta Metrik

Harian Kompas melansir dari AFP pada hari sabtu (2/6/2018), seekor paus pilot mati di perairan provinsi Songkhla, Thailand Selatan setelah menelan sekitar 80 kantong plastik. Setelah diotopsi, berat plastik dalam tubuh paus tersebut mencapai $8 \mathrm{~kg}$. Setidaknya ada 300 hewan laut termmasuk paus pilot, penyu, dan lumba-lumba mati setiap tahun di perairan Thailand karena menelan plastik. Selain itu plastik di laut juga akan menghambat perjalanan kapal (pemborosan bahan bakar), mengganggu estetika di daerah wisata (kerugian dunia pariwisata), dan kesehatan (Qiu et al., 2015).

Akumulasi sampah laut disebabkan oleh pembuangan sampah oleh masyarakat yang disebabkan karena kurangnya pengetahuan masyarakat tentang sampah. Masyarakat perlu memiliki pengetahuan yang baik tentang sampah, 
sehingga mereka akan memiliki kesadaran pentingnya pengelolaan sampah laut. Penanganan sampah permukiman memerlukan partisipasi aktif individu dan kelompok masyarakat selain peran pemerintah sebagai fasilitator. Dengan meningkatnya kualitas lingkungan laut yang bebas dari sampah maka kualitas hidup masyarakat meningkat (Marojahan, 2015).

Sehubungan dengan hal tersebut di atas, Pantai Kuranji Lombok Barat telah difasilitasi berbagai bangunan oleh pemerintah daerah sebagai daerah wisata. Dari hasil pengamatan lokasi wisata tersebut cukup menarik karena menghadap matahari terbenam dan hamparan pantai yang cukup luas. Kendala yang dihadapi adalah masih adanya masyarakat yang bermukin di pantai tersebut belum mengelola sampah dengan baik. Di samping itu sampah laut yang terbawa arus dari luar juga menambah banyaknya kumulasi sampah di pantai. Apabila keadaan tersebut dibiarkan maka tujuan pemerintah untuk menjadikan pantai wisata dapat terhambat.

Program ini bertujuan untuk memberikan edukasi/kesadaran kepada masyarakat Pantai Kuranji (Siswa SMP N 17 Mataram): (1) bahaya sampah (terutama plastik), (2)cara menjaga kebersihan pantai.

Manfaat yang diperoleh dari kegiatan ini adalah sebagai berikut: (1) Dengan timbulnya kesadaran masyarakat pesisir terhadap kebersihan pantai terutama akibat sampah, diharapkan dapat mendukung program pemerintah terhadap kebersihan laut. (2) Dengan adanya kegiatan ini diharapkan dapat dijadikan dasar bagi instansi terkait terutama Pemda dalam upaya pengelolaan sampah di pantai.

\section{Metode Pelaksanaan}

Untuk mencapai target dalam kegiatan ini, maka ada beberapa tahapan implementasi program pengbadian yaitu:

\section{Sasaran Kegiatan}

Sasaran kegiatan ini adalah masyarakat pesisir di Pantai Kuranji dalam hal ini adalah Siswa SMP N 17 Mataram.
Metode yang digunakan dalam kegiatan pendampingan ini meliputi sosialisasi dan diskusi, dengan langkah-langkah sebagai berikut: (1) Tahap persiapan, beberapa kegiatan yang dilakukan pada tahapan ini meliputi: menyusun ToR (Term of Reference), identifikasi calon peserta, workshop internal tim pengabdian (seperti penentuan waktu pelatihan, tempat, materi pelatihan), pengurusan izin pelaksanaan kegiatan pengabdian. (2) Tahap sosialisasi, dalam kegiatan yang dilakukan pada tahapan ini antara lain memberikan sosiaisasi kepada Siswa SMP N 17 Mataram yang berlokasi daerah pesisir di Pantai Kuranji. Oleh karena sosialisasi ini bertujuan memberi kesadaran terhadap kebersihan laut. Oleh karena itu, maka hal-hal yang ditampilkan adalah suatu peristiwa terkait dengan sampah laut berupa: gambar, data, atau video yang disertai dengan diskusi tanyajawab.

\section{Analisis Data}

Data yang diambil dalam kegiatan ini berupa data kualitatif dan data kuantitatif. Data kualitatif merupakan data yang diperoleh selama kegiatan sisialisasi, prakterk dan evaluasi. Data tersebut diperoleh dari pengamatan langsung dan dijelaskan secara deskriptif. Data kuantitatif merupakan data jumlah dan berat sampah yang dianalisis menggunakan komputer program Excel dan disajikan dalam bentuk angka dan grafik.

\section{Hasil dan Pembahasan}

Kegiatan pengabdian pada masyarakat tentang kesadaran bahaya sampah laut telah dilakukan pada Siswa SMP N 17 Mataram tepatnya di lokasi sekitar Pantai Kuranji. Teknik yang digunakan adalah penyuluhan yang menyajikan dua hal yaitu: (1) terkait dengan kesadaran masyarakat akan kebersihan pantai dan (2) terkait dengan cara mengumpulkan/mengkoleksi sampah-sampah laut.

Dalam rangka memberikan kesadaran pada masyarakat/Siswa SMP N 17 Mataram, maka sebelum kegiatan siswa disuruh mengisi angket yang mengungkap indikator pemahaman siswa tentang kebersihan laut sebagaimana tercantum dalam tabel 1 berikut.

Tabel 1. Indikator Pemahaman Siswa Terhadap Kebersihan Laut

\section{Metode}




\begin{tabular}{cl}
\hline No & Indikator \\
\hline 1 & Larangan membuang sampah di laut \\
2 & $\begin{array}{l}\text { Pencemaran laut disebabkan pembuangan } \\
\text { sampah di sungai }\end{array}$ \\
3 & Laut kita sudah banyak dicemari sampah \\
4 & Bahayanya sampah plastik di laut \\
5 & Sampah mikroplastik banyak terdapat di laut \\
& Bahayanya sampah mikroplastik bagin \\
6 & kesehatan \\
8 & Kerugian sampah laut bagi pariwisata \\
\hline
\end{tabular}

Kegiatan selanjutnya adalah penyajian gambar dan penjelasan terkait kebersihan laut dan diakhiri dengan diskusi/tanya jawab. Penyajian gambar pertama adalah gambar 1 yang mengambarkan perbedaan laut yang tercemar sampah dengan laut yang bersih.
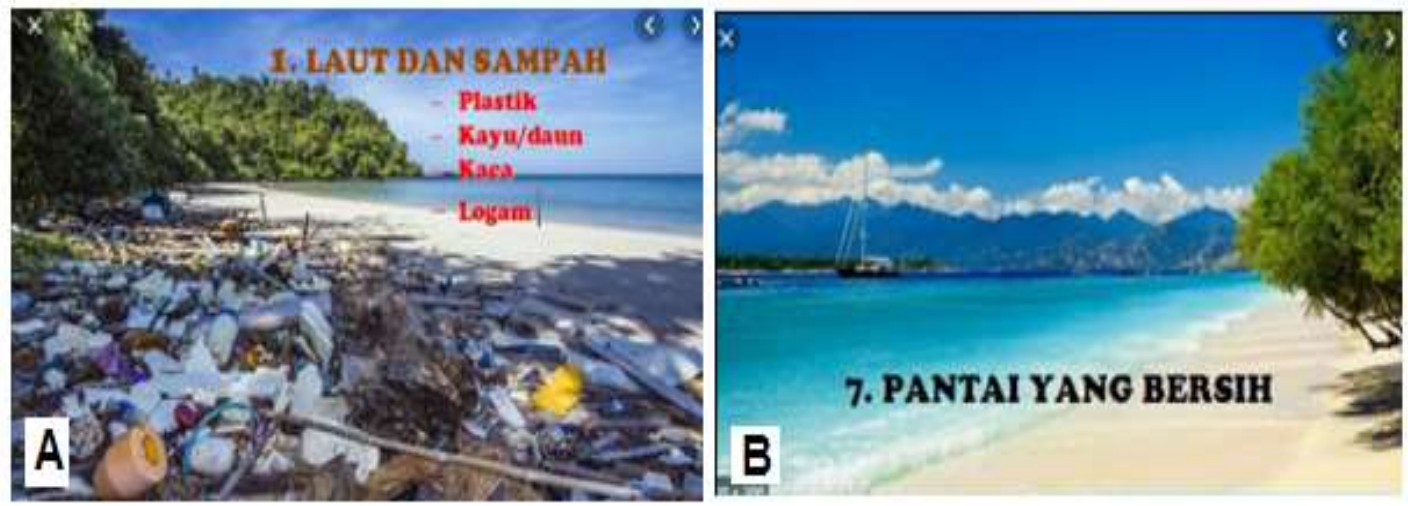

Gambar 1. Perbedaan laut tercemar sampah dengan laut bersih

Dengan waktu sekitar 2 - 5 menit para siswa disuruh memperhatikan gambar, kemudian siswa mengamati gambar tersebut dan menjawab pertanyaan lisan, (1) apa perbedaan gambar A dengan gambar B?, (2) apakah laut di sekitar kita sudah menunjukan keadaan seperti gambar A, (3) laut mana yang kondisinya lebih baik ? (4) apa yang menyebabkan perbedaan tersebut ?. Keadaan siswa saat mengikuti penjelasan dan menjawab pertanyaan oleh tim pengabdian terlihat dalam foto gambar 2.
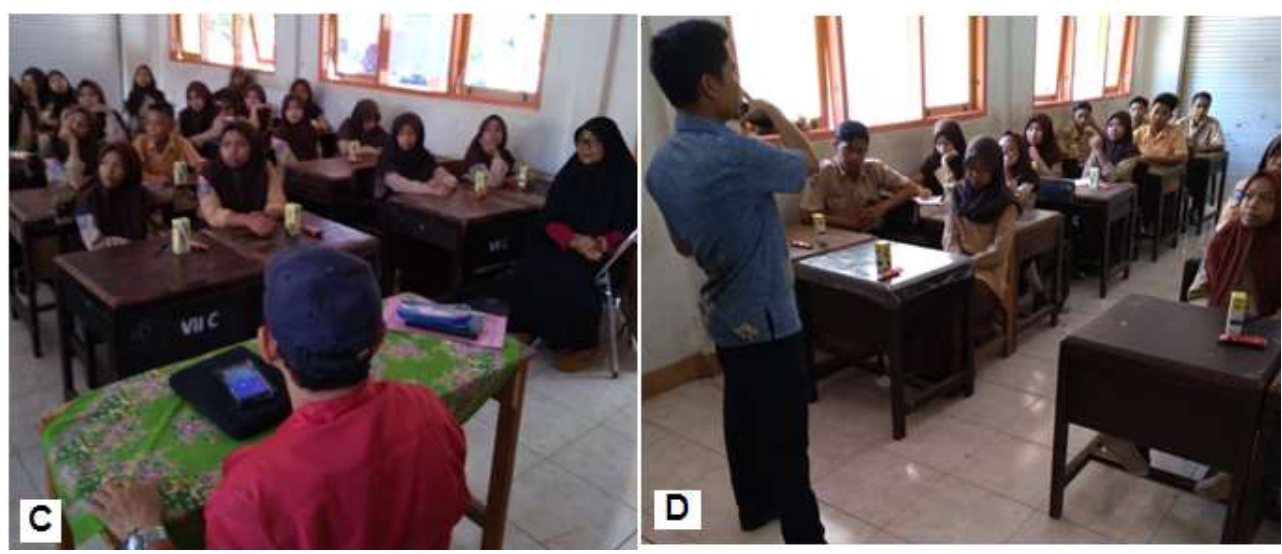

Gambar 2. Suasana siswa saat penjelasan dan tanya jawab

Berdasarkan gambar 2 menunjukan bahwa siswa menunjukan perhatian yang tinggi terhadap media foto maupun penjelasan dari tim (gambar A). Selanjutnya saat diskusi/menjawab pertanyaan juga sebagian besar siswa dapat menjawab pertanyaan dengan baik dan keseriusan yang tinggi (gambar B). Hasil diskusi mengenai hasil analisis gambar dapat disimpulkan dalam tabel 2 . 
Tabel 2. Hasil Diskusi Siswa Tentang Laut Bersih dan Kotor

\begin{tabular}{ll}
\hline No & Hasil Diskusi Siswa \\
\hline (1) & $\begin{array}{l}\text { Gambar2 A menunjukan laut yang bersih dan } \\
\text { gambar B menunjukan laut yang kotor } \\
\text { Banyak dijumpai laut kita terutama di pantai } \\
\text { (2) }\end{array}$ \\
(3) & $\begin{array}{l}\text { Laut pada geperti gambar A } \\
\text { kondisinya baik dan menyenangkan }\end{array}$ \\
(4) & Penyebab perbedaan kondisi laut pada gambar \\
& A dan B adalah karena adanya sampah yang \\
berada di laut
\end{tabular}

Penyajian berikutnya adalah terkait dengan pencemaran sampah plastik dan mikroplastik. Mengingat bahwa pencemaran sampah plastik di laut memiliki dampak negatif yang cukup besar, maka tim memberikan penjelasan yang cukup dalam. Selain itu, sampah plastik dalam ukuran mikro juga merupakan pencemar yang cukup berbahaya dan belum dikenal secara jelas oleh masyarakat/siswa. Langkah awal dalam kegiatan ini adalah menampilkan gambar berupa efek sampah plastik dan mikroplastik pada biota laut (ikan)

Dalam kegiatan ini peserta/siswa disuruh mengamati gambar yang berhubungan dengan sampah plastik dan mikroplastik. Sebagian besar siswa tidak memahami maksud gambar tersebut. Oleh sebab itu tim peneliti menjelaskan secara keseluruhan secara rinci. Diakhir penjelasan siswa disuruh mengambil kesimpulan sebagaimana tercantum dalam tabel 3.

Tabel 3. Hasil Diuskusi Siswa Tentang Sampah Plastik dan Mikroplastik

\begin{tabular}{|c|c|}
\hline No & Hasil Diskusi Siswa \\
\hline (1) & $\begin{array}{l}\text { Gambar3A ikan paus yang mengakumulasi } \\
\text { sampah platik, sehingga meninggal }\end{array}$ \\
\hline (2) & $\begin{array}{l}\text { Gambar } 3 B \text { menunjukan ikan yang terjerat } \\
\text { sampah plastik, sehingga kehidupannya } \\
\text { terganggu }\end{array}$ \\
\hline (3) & $\begin{array}{l}\text { Gambar } 3 C \text { menunjukan sampah plastik yang } \\
\text { telah hancur dengan ukuran kecil-kecil sehingga } \\
\text { membentuk mikroplastik }\end{array}$ \\
\hline (4) & $\begin{array}{l}\text { Gambar 3D menunjukan mikroplastik yang } \\
\text { masuk ke daging/jaringan ikan, sehingga } \\
\text { membahayakan } \quad \text { manuasia } \\
\text { mengkonsumsinya }\end{array}$ \\
\hline
\end{tabular}

Kegiatan terakhir penyuluhan adalah menampilkan foto atau gambar siswa membuang sampah di laut. Pada kegiatan ini siswa disuruh mengamati gambar tersebut. Namun tanpa dijelaskan oleh tim, para siswa langsung member tanggapan bahwa gambar tersebut menunjukan perbuatan manusia yang tidak benar. Oleh karena itu tim peneliti yakin bahwa para peserta telah memiliki kesadaran terhadap kebersihan laut.

Berdasarkan data yang diuraikan pada hasil kegiatan tersebut, maka tim peneliti memiliki hipotesis bahwa kegiatan tersebut telah mampu memberikan kesadaran siswa terhadap kebersihan laut. Namun demikian untuk dapat meyakinkan maka di akhir kegiatan siswa diberikan angket. Skor hasil angket di awal dan di akhir kegitan disajikan dalam tabel 4.

Tabel 4. Skor Hasil Angket Siswa Sebelum dan Sesudah Kegiatan

\begin{tabular}{|c|c|c|c|}
\hline \multirow[t]{2}{*}{ No } & \multirow[t]{2}{*}{ Indikator } & \multicolumn{2}{|c|}{ Persentase } \\
\hline & & Sebelum & Sesudah \\
\hline 1 & $\begin{array}{l}\text { Kita boleh membuang } \\
\text { sampah di laut }\end{array}$ & 70 & 100 \\
\hline 2 & $\begin{array}{l}\text { Membuang sampah di } \\
\text { sungai dapat } \\
\text { mencemari laut }\end{array}$ & 67 & 80 \\
\hline 3 & $\begin{array}{l}\text { Laut kita banyak } \\
\text { dikotori sampah }\end{array}$ & 70 & 100 \\
\hline 4 & $\begin{array}{l}\text { Sampah plastik yang } \\
\text { berada di laut }\end{array}$ & 73 & 100 \\
\hline 5 & $\begin{array}{l}\text { Di laut banyak } \\
\text { terdapat sampah } \\
\text { mikro-plastik }\end{array}$ & 20 & 90 \\
\hline 6 & $\begin{array}{l}\text { Sampah mikroplastik } \\
\text { dapat masuk ketubuh } \\
\text { ikan dan bahaya bagi } \\
\text { yang memaknnya }\end{array}$ & 27 & 93 \\
\hline 7 & $\begin{array}{l}\text { Sampah laut dapat } \\
\text { merugikan pariwisata }\end{array}$ & 67 & 100 \\
\hline 8 & $\begin{array}{l}\text { Sampah laut dapat } \\
\text { merugikan nelayan } \\
\text { Rata-rata }\end{array}$ & $\begin{array}{l}60 \\
57\end{array}$ & $\begin{array}{c}100 \\
95\end{array}$ \\
\hline
\end{tabular}

Berdasarkan data pada tabel 4 tersebut menunjukan bahwa skor pemahaman siswa terhadap pencemaran laut sebelum dan sesudah kegiatan adalah berbeda secara kuantitatif. Hal-hal yang masih kurang dipahami/disadari pada siswa (di bawah 70\%) adalah mengenai: sampah mikroplastik, bahaya mikroplastik, kerugian nelayan dan pariwisata akibat sampah laut, dan dampak membuang sampah di sungai terhadap pencemaran laut.

Setelah siswa mengikuti penjelasan secara sistematik dengan memberikan contoh-contoh kongkrit dan menjelaskan penyebab, proses dan akibat yang terjadi maka siswa dapat memahami dengan baik, sehingga skor hasil akhir menunjukan nilai yang tinggi. Hal ini menunjukan bahwa siswa 
telah memiliki pemahaman yang baik terhadap kebersihan laut. Perubahan pemahaman siswa terhadap kebersihan laut sebagai efek dari penyuluhan ini dapat ditunjukan dalam gambar 3 .

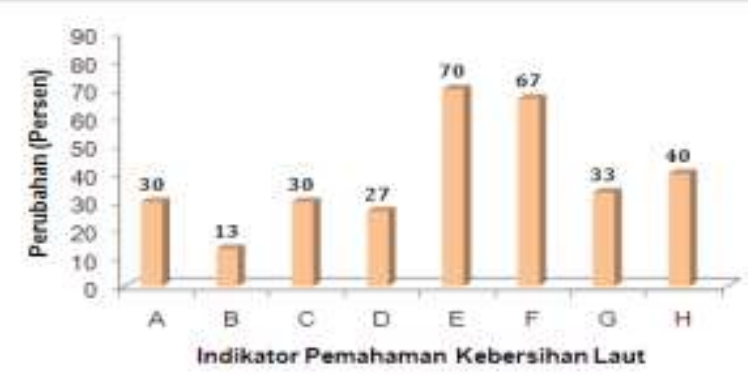

Gambar 3. Diagram perubahan pemahaman siswa terhadap kebersihan laut setelah kegiatan penyuluhan

Berdasarkan data kuantitatif tersebut menunjukan bahwa setelah kegiatan pengabdian terjadi peningkatan pemahaman siswa terhadap kebersihan laut. Berdasar data kualitatif sebagaimana diuraikan di hasil kegiatan juga menunjukan adanya perhatian tinggi terhadap kebersihan laut. Oleh karena itu dapat diartikan bahwa kegiatan penyuluhan ini dapat meningkatkan kesadara siswa terhadap kebersihan laut. Hal tersebut sesuai dengan pendapat Chalmers (1995) bahwa kesadaran digambarkan sebagai keadaan mental yang berisi dengan hal- hal proposisional, seperti misalnya keyakinan, harapan, kekhawatiran, dan keinginan.

\section{Kesimpulan}

Dari hasil kegiatan pengabdian masyarakat ini dapat diambil kesimpulan sebagai berikut: (1) Telah dibuat media untuk kegiatan penyuluhan berupa poster tentang pencemaran laut dan efeknya terhadap kehidupan, (2) Dari hasil observasi, diskusi dan tanya jawab, serta tes sikap siswa, menunjukkan bahwa melalui kegiatan penyuluhan ini pengetahuan siswa tentang bahaya sampah laut meningkat, (3) Dari hasil observasi, diskusi dan tanya jawab, serta tes sikap siswa, menunjukkan bahwa melalui kegiatan penyuluhan ini kesadaran siswa terhadap bahaya sampah laut meningkat.

\section{Ucapan Terimakasih}

Terima kasih disampaikan kepada Universitas Mataram yang telah mendanai kegiatan ini melalui Dana PNBP Unram tahun 2019

\section{Daftar Pustaka}

Chalmers, D.J. 199b. The Puzzle of Conscious Experience. Scientific American, Vol. 273 (6): 90-100.

Jambeck, J.R., R. Geyer, C. Wilcox, T. R. Siegler, M. Perryman, A. Andrady, R. Narayan, K. L. Law. 2015. Plastic waste inputs from land into the ocean. Science, 347 (6223): 768 - 771.

Lebreton, L. W. 2017. River Plastic Emissions to the World's Oceans. . Nature Communications, 8, 15611.

Marojahan, R. 2015. Hubungan Pengetahuan Masyarakat Tentang Sampah Dengan Perilaku Mengelola Sampah Rumah Tangga Di Rt 02 Dan Rt 03 Kampung Garapan Desa Tanjung Pasir Kecamatan Teluk Naga Kabupaten Tangerang. Forum Ilmiah Volume 12 Nomor 1, 33-44.

Moore, J. C., Spink, J., dan Lipp, M.. 2012. Development and application of a database of food ingredient fraud and economically motivated adulteration from 1980 to 2010. Journal of Food Science, 77(4).

National Oceanic and Atmospheric Administration. 2013. Programmatic Environmental Assessement (PEA) for the NOAA Marine Debris Program (MDP). Maryland (US): NOAA.

Qiu Q, Peng J, Yu X, Chen F, Wang J, Dong F. 2015. Occurrence of microplastics in the coastal marine environment: First observation on sediment of China. Mar Pollut Bull. 98:274-280. 